Al-Mashrafiyah: Jurnal Ekonomi, Keuangan dan Perbankan Syariah ISSN (p): 2597-4904 ISSN (e) : 2620-5661

Volume 5, Nomor 1, April (2021), h. 1-14

10.24252/al-mashrafiyah.v5i1.20022

\title{
Service Quality And Corporate Image To The Customer Loyalty Of BPRS Baktimakmur Indah Sepanjang Sidoarjo
}

\author{
Rochmatin Nikmah ${ }^{1}$, Syarifudin ${ }^{2}$ \\ Universitas Islam Negeri Sunan Ampel Surabaya ${ }^{12}$ \\ rochmatin15@gmail.com ${ }^{1}$, udinsyarif1109@gmail.com ${ }^{2}$
}

Received: 27-02-2021; Revised: 25-03-2021; Accepted: 26-04-2021;

Keywords:
Service Quality, Corporate
Image, Customer Loyalty

Kata Kunci:

Kualitas Layanan, Citra Perusahaan, Loyalitas Nasabah

\section{ABSTRACT}

In line with the increasingly intense business competition in all sectors, Islamic banking needs to enbance the company's quality to compete and maintain its existence. One of the keys to success is building customer loyalty. This study aimed to analyze the effect of service quality and corporate image on customer loyalty of BPRS Baktimakmur Indah Sepanjang, Sidoarjo. This research was associative quantitative research, data collection was done through observation and questionnaires with the purposive sampling method. The results revealed that service quality had no significant effect, while corporate image had a significant effect on customer loyalty. However, it simultaneously indicated a quite strong influence. This study found that the indicator with the most dominant influence on service quality was fulfilled expectations, especially in terms of pick-up service. Meanwbile, the corporate image was an indicator of company characteristics, especially the location of the BPRS which was strategic and easily accessible. Thus, it is hoped that the BPRS Baktimakmur Indah Sepanjang, Sidoarjo can enhance service and product quality and be able to maintain its reputation consistently.

\section{ABSTRAK}

Seiring semakin ketatnya persaingan bisnis dalam segala sektor, perbankan syariah harus meningkatkan kualitas perusahaan agar dapat bersaing dan mempertahankan eksistensinya. Salah satu kunci keberhasilannya adalah dengan menciptakan loyalitas nasabah. Penelitian ini bertujuan untuk menganalisis pengaruh service quality serta corporate image terhadap loyalitas nasabah tabungan BPRS Baktimakmur Indah Cabang Sepanjang, Sidoarjo. Penelitian ini merupakan penelitian kuantitatif asosiatif, pengumpulan datanya dilakukan melalui observasi dan kuesioner dengan metode purposive sampling. Hasil penelitian menunjukkan bahwa service quality tidak berpengaruh signifikan, sedangkan corporate image berpengaruh signifikan terhadap loyalitas nasabah. Namun, secara simultan menunjukkan pengaruh cukup kuat. Studi ini menemukan indikator yang berpengaruh paling dominan dari service quality adalah indikator memenuhi harapan terutama dari segi pick up service. Sedangkan dari corporate image adalah indikator karakteristik perusahaan terutama lokasi BPRS yang strategis dan mudah diakses. Dengan demikian, diharapkan BPRS Baktimakmur Indah Cabang Sepanjang, Sidoarjo dapat meningkatkan kualitas pelayanan maupun produk serta mampu menjaga reputasinya secara konsisten. 


\section{INTRODUCTION}

In the current Covid-19 pandemic, the Indonesian government decided to pay more attention to three sectors, specifically health, the real sector, and banking (Manurung \& Fitrawaty, 2016). This causes the world of Islamic banking to grow quite rapidly and has resulted in increasingly competitive interbank competition (Mutmainnah, 2017). Thus, it encourages numerous innovations that aim to facilitate accessibility for customers in transactions without direct contact to comply with social distancing health protocols. One of them is digital transformation in banking technology (Ilham \& Hariyani, 2020).

The competitive strategy of the sharia banking industry after the implementation of the ASEAN Economic Community (AEC) in Indonesia in response to conventional banking strategies is to improve quality and stick to sharia principles (Pratomo, 2017). In this case, the government has begun to develop a fintech-based financial technology industry, so this sector is expected to encourage convenience for society in the method of financial services (Hidayat, 2018). From the observations, it appears that the level of customer satisfaction in the services provided still needs to be improved (Zumaroh, 2018). This can be seen from the number of BPR and BPRS that will conduct mergers due to the decline in bank financial performance (Naufal \& Firdaus, 2017). Therefore, it is crucial to enhance the service quality both in terms of products and services by the banks to maintain the sustainability of the company (Nasfi et al., 2020).

Besides, sharia financial institutions need to approach as well as provide understanding to the public about the significance of sharia principles in financial literacy. Thus, it is vital to have an Islamic branding strategy that is part of a marketing strategy that can build the corporate image (Wijanarko \& Rachmawati, 2020). This is due to the fact that numerous people are getting interested in sharia banking but there is still minimal outreach of sharia financial literacy itself. Whereas people tend to use a product or service because of good perceptions of a company both in terms of service and the impression given (Nurhayati, 2018).

The development of the number of Sharia Rural Banks in 2019 was as many as 164 banks, which decreased by 3 banks from the previous year, although there was an increase in the number of bank offices by 619 from 495 offices in 2018 throughout Indonesia (Badan Pusat Statistik, 2020). The following is data on third party funds and the amount of BPRS financing in Indonesia from 2018 to 2020:

Table 1: Data on DPK Composition - Sharia Rural Banks 2018-2020

\begin{tabular}{|c|c|c|c|}
\hline Indicator & 2018 & 2019 & 2020 \\
\hline \multicolumn{4}{|l|}{ iB Giro - Wadiah Contract } \\
\hline iB Savings & 2.998 .201 & 3.202 .792 & 3.371 .706 \\
\hline a. Wadiah Contract & 1.738 .702 & 1.873 .868 & 1.993 .120 \\
\hline b. Mudharabah & 1.259 .499 & 1.328 .924 & 1.378 .586 \\
\hline Contract & & & \\
\hline \multicolumn{3}{|l|}{ Mudharabah } & 6.447 .337 \\
\hline a. 1 Month & 538.766 & 392.842 & 558.322 \\
\hline b. 3 Months & 782.724 & 634.705 & 731.464 \\
\hline c. 6 Months & 901.025 & 731.535 & 781.756 \\
\hline d. 12 Months & 2.880 .772 & 2.812 .410 & 3.402 .542 \\
\hline e. $>12$ Months & 33.449 & 957.605 & 973.253 \\
\hline Total & 8.134 .938 & 8.731 .890 & 9.819 .043 \\
\hline
\end{tabular}

Source: Financial Services Authority SPS Data Processed (2020) 
Table 2: Financing Data provided by Sharia Rural Banks 2018-2020

\begin{tabular}{lrrr}
\hline \multicolumn{1}{c}{ Contract } & \multicolumn{1}{c}{$\mathbf{2 0 1 8}$} & \multicolumn{1}{c}{$\mathbf{2 0 1 9}$} & \multicolumn{1}{c}{$\mathbf{2 0 2 0}$} \\
\hline Mudharabah & 180.956 & 240.606 & 260.651 \\
Musharakah & 837.915 & 1.121 .004 & 1.551 .953 \\
Murabaha & 6.940 .379 & 7.457 .774 & 7.648 .501 \\
Salam & 0 & 0 & 0 \\
Istisna & 35.387 & 67.178 & 72.426 \\
Ijarah & 46.579 & 41.508 & 53.318 \\
Qard & 185.360 & 176.856 & 222.678 \\
Multi-service & 857.890 & 838.394 & 871.973 \\
\hline \multicolumn{1}{r}{$\quad$ Total } & $\mathbf{9 . 0 8 4 . 4 6 7}$ & $\mathbf{9 . 9 4 3 . 3 2 0}$ & $\mathbf{1 0 . 6 8 1 . 4 9 9}$ \\
\hline
\end{tabular}

Source: Financial Services Authority SPS Data Processed (2020)

From the table 1 and table 2, it is known that the third party funds collected and the financing provided by BPRS in Indonesia have continually increased. This shows that there are opportunities as well as challenges for Islamic banking to increase competitiveness against other banks (Yudha et al., 2020). With its impressive development progress that has achieved an average asset growth of more than $65 \%$ per year in the last five years, the role of the Islamic banking industry in supporting the national economy has become increasingly significant (Apriyanti, 2017).

This increasingly fierce competition motivates all elements of the existing organization to continue to improve quality and productivity (Nurhayati, 2018). The key to the success of an organization depends on the number of customers or customers who continue to use the company's services, both products and services, or often referred to as customer loyalty (Sulaeman et al., 2017). This customer loyalty can be seen from several influencing aspects, including service quality and corporate image (Purnama \& Hidayah, 2019).

This is in line with the research results conducted by Ardhila Laela Kusumastuti and M. Abdul Kodir in a journal entitled "Analysis of Service Quality on Customer Loyalty at the Bank of Central Java's Sampangan Sub-Branch" which concluded that service quality variables have a simultaneous or partial effect on customer loyalty (Kusumastuti \& Kodir, 2019). According to Tjiptono, service quality is the level of excellence expected and control over these advantages to fulfill desires (Tjiptono \& Chandra, 2011). Based on the results of previous research in a journal written by Safraz Ashraf, Rashid Ilyas, Majid Imtiaz, and Sajjad Ahmad entitled "Impact of Sevice Quality, Corporate Image and Perceived Value on Brand Loyalty with Presence and Absence of Customer Satisfaction: A Study of Four Service Sectors of Pakistan," explained that in addition to service quality, a factor affecting customer loyalty is the corporate image. Corporate image is a consumer's perception or view of an organization or company (Ashraf et al., 2018). Customers will tend to be attracted to companies that have a good track record as well as a good image in the public eyes. Hence, further research is required to examine the effects of service quality and corporate image simultaneously rather than separately. Where the most significant indicator of service quality is being able to meet customer expectations.

BPRS Baktimakmur Indah Sepanjang was founded in 1994 and is the oldest sharia banking in the Sepanjang area but still exists today amid increasingly fierce competition. Based on the narrative from the Head Officer of BPRS Baktimakmur Indah Sepanjang, the development of the number of savings customers, both wadhiah savings and time deposits, has always increased from month to month. The latest data in December reached 11.627 customers and almost $75 \%$ were active customers. 
Table 3: Customer Development Data for BPRS Baktimakmur Sepanjang, Sidoarjo September - December 2019

\begin{tabular}{cccccc}
\hline \multirow{2}{*}{ NO } & TYPE OF & \multicolumn{4}{c}{ MONTHS } \\
\cline { 3 - 6 } & FINANCE & September & October & November & December \\
\hline 1. & DEPOSIT & 309 & 308 & 307 & 309 \\
2. & WADHIAH & 2.573 & 2.589 & 2.665 & 2.649 \\
3. & MUDHARABAH & 8.632 & 8.640 & 8.627 & 8.669 \\
\hline & TOTAL & 11.514 & 11.537 & 11.599 & 11.627 \\
\hline
\end{tabular}

Source: BPRS Baktimakmur Indah Processed Data (2019)

This figure is the reason why the researchers decided to examine the level of customer loyalty at BPRS Baktimakmur Indah Sepanjang, Sidoarjo. To assess the service quality provided by BPRS Baktimakmur Indah Sepanjang, Sidoarjo to customers, researchers focused on indicators of fulfilled expectations, attention, and responsiveness (Sholeha et al., 2018). The advantage of the services provided by BPRS Baktimakmur Indah Sepanjang, Sidoarjo compared to other sharia banking around the work area is the pick-up service as a form of supporting service (Asrina \& Bulutoding, 2017) with minimum deposit funds of only Rp. 10.000.00 and free of charge. Also, along with the funding process with the pick-up service, cash withdrawals can be made on the spot. This is aimed at efficiency and effectiveness for customers which have an impact on customer satisfaction (Rahman, 2019).

\section{LITERATURE REVIEW}

According to Kotler (2012), service quality is a standardized measure determined by consumers on how well the level of service provided by service providers meets consumer expectations and needs (Andra Miranthi, 2017). The higher the quality level provided, the higher the level of customer satisfaction which will have an impact on customer loyalty itself and will be a competitive advantage for the company (Purbasari \& Purnamasari, 2018). Meanwhile, Lewis \& Booms (in Tjiptono, 2012) defines service quality as a measure of how appropriate the level of service provided is with customer expectations (Haeriah \& Rahayu, 2018). Service quality can be seen from the ability to provide services accurately as promised and consistently deliver higher quality than competitors.

According to Xian and Gou (2011), Corporate Image is the impression, perception, and image of consumers on an organization or company which includes the company's credibility, the company's distribution network, and the company's popularity (Mandong et al., 2017). In creating a positive and good corporate image (Sukoco et al., 2020), companies need to send messages to the public and the environment both internally and externally, such as advertisements or word of mouth which will affect the process of forming the company's image (Purnama \& Hidayah, 2019).

According to Lovelock and Wirtz (2011), customer loyalty is a customer's decision to voluntarily continue to subscribe to a certain company for a long period (Thungasal \& Siagian, 2019). Customer loyalty is the key to a company's success because of its strategic value (Putra \& Ekawati, 2017). Customer loyalty will arise when the customer is satisfied with the products or services provided (Dewi \& Suprapti, 2018). A high level of satisfaction can increase customer loyalty, prevent customer turnover, reduce price sensitivity, increase advertising effectiveness, and improve business reputation (Tuju \& Loindong, 2018). Loyal customers commit to always use the products they choose that are considered the most suitable for their needs and tend to defend the company from these products.

Sharia smallholder credit bank is a sharia credit bank as regulated in Government Regulation No. 21 of 2008, is a smallholder credit bank whose activities are based on the principles of profit sharing and risk sharing and are free from the element of usury (Hanif \& Fitri, 2018). BPRS as sharia banking has a vision and mission of being a trusted platform for the public to invest fairly by following sharia principles (Abshari \& Hasib, 2018). Besides, BPRS also maintains and 
manages funds from customers in a good, honest, trustworthy, and transparent manner (Syarifudin et al., 2020). BPRS does not provide services in payment traffic. According to Sudarsono (2013), sharia bank products basically offer three products: funding, lending, and service. According to Muhammad (2014), funding includes demand deposits, savings, and deposits using the principles of wadhiah and mudharabah (Habibi \& Yudha, 2017), while lending uses the principles of $b a^{\prime} i$ almurabahah, as-salam, al-istishna', ijarah, musyarakah, and mudharabah (Samsul \& Ismawati, 2020).

\section{RESEARCH METHODS}

This research was conducted using an associative quantitative approach, a research using statistical techniques and data analysis which aims to determine the relationship between two or more variables. This study consisted of service quality and corporate image as the dependent variable and customer loyalty as the independent variable. The population in this study was 11,627 customers of wadhiah savings and deposits of PT. BPRS Baktimakmur Indah Sepanjang, Sidoarjo, while for the samples taken, the researcher uses the Slovin formula with a confidence level of $90 \%$ (error 0.10) (Sugiyono, 2011) is as follows:

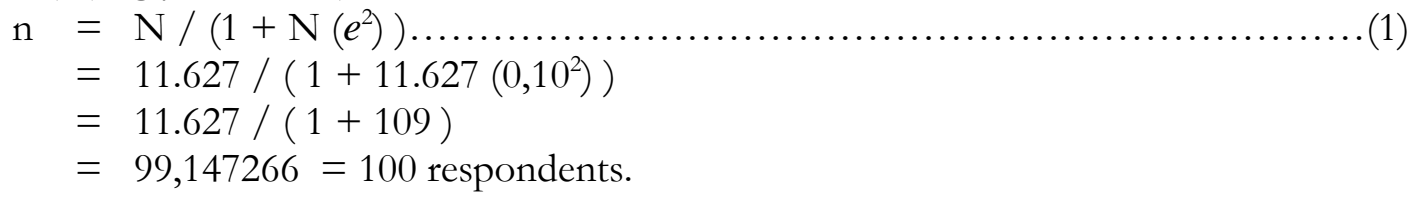

Where:

$$
\begin{aligned}
& \mathrm{n}=\text { Sample size } \\
& \mathrm{N}=\text { Population size } \\
& e=\text { Margin of error }
\end{aligned}
$$

This study used a non-probability sampling technique with the purposive sampling method (Sugiyono, 2012). The criteria for respondents were savings customers at BPRS Baktimakmur Indah Sepanjang, Sidoarjo, at least a high school education level and are more than 18 years old. These criteria were chosen so that respondents understand the statements in the questionnaire given.

The data used in this study is cross-sectional data with data sources consisting of primary data and secondary data (Silalahi, 2012). Primary data was obtained by giving questionnaires and directing interviews to customers of BPRS Baktimakmur Indah Sepanjang, Sidoarjo. Meanwhile, secondary data was data related to companies that have been published such as literature studies, previous research, journals, or other literature related to this research.

This study used multiple linear regression analysis techniques, an analysis to determine the effect of independent variables (service quality and corporate image) on the dependent variable (customer loyalty) of BPRS Baktimakmur Indah Sepanjang, Sidoarjo (Oktrima \& Riani, 2019). In this study, the equation model in multiple linear regression analysis is as follows:

$$
\mathbf{Y}=\alpha+\beta_{1} \mathbf{X}_{1}+\beta_{2} \mathbf{X}_{2}+e .
$$

This analysis is used to examine the relationship between two or more variables, especially to trace the pattern of relationships whose models are not yet fully known. The following is the conceptual and operational framework of the research variables described as follows: 
Figure 1: Conceptual Framework

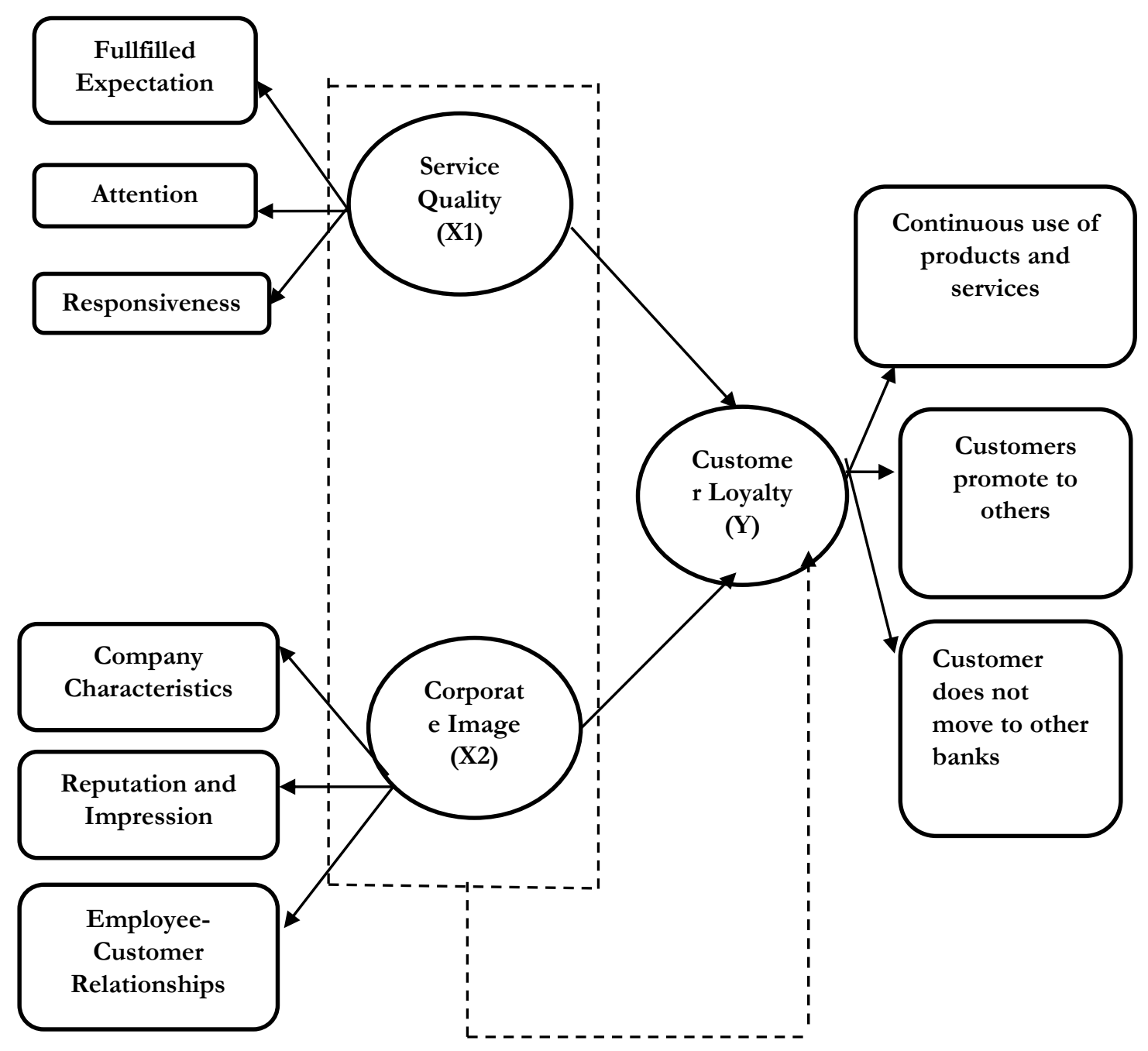

\section{Information:}

$\mathrm{X} 1=$ First independent variable

$\mathrm{X} 2=$ Second independent variable

$\mathrm{Y}=$ Dependent variable 


\section{RESULTS AND DISCUSSION}

Before interpreting the results of multiple linear regression tests, to determine the accuracy of the research instrument in measuring the variables under study, the researchers tested the validity of the variable service quality, corporate image, and customer loyalty. Based on the results of the validity test, it was known that all instruments of each variable were valid because all instruments had a calculated $r$-value $>\mathrm{r}$ table or more than 0.196. Furthermore, to determine the degree of instrument consistency, the researchers conducted an instrument reliability test with the result that all instruments in this study were reliable because they had a Cronbach's Alpha value above 0.8 .

\section{Classical Assumption Test Normality test}

The normality test aims to test the normal distribution of the residuals in the regression model. In this study, the Kolmogorov-Smirnov (K-S) test was used with the help of the Minitab 18 tools (Padilah \& Adam, 2016) and the following results were obtained:

Table 4. Normality Test Result

\begin{tabular}{lcr}
\hline \multicolumn{2}{c}{ One-Sample Kolmogorov-Smirnov Test } & Result \\
\hline $\mathrm{N}$ & .134 & Normal \\
\cline { 1 - 2 } Asymp. Sig. (2-tailed) & $.000^{\mathrm{c}}$ & \\
\hline \multicolumn{2}{c}{ Source: SPSS Ver.23 Output Processed (2020) }
\end{tabular}

Based on the results of data processing, it was known that the significance value of Asymp. Sig. (2-tailed) was $0.000<0.05$, which means that the residual data was normally distributed. Furthermore, the normality test was carried out using a normal probability plot which shows that the data distribution is around the diagonal line area and follows the direction of the diagonal line, this means that the data in the study has met the normal probability plot requirements so that the regression model also meets the assumption of normality.

\section{Multicollinearity Test}

The multicollinearity test aims to test whether there is a correlation between the independent variables (service quality and corporate image) in the regression model or not (Wati \& Isroah, 2019). The multicollinearity test in this study used the Variance Inflation Factor (VIF) and the following results were obtained:

Table 5. Multicolonierity Test Results - Dependent Variable: Customer Loyalty

\begin{tabular}{cccc}
\hline \multicolumn{4}{c}{ Collinearity Statistics : Coefficients Test } \\
\hline Model & Tolerance & VIF & Result \\
\hline Service Quality & 0,914 & 1,094 & It has Multicolonierity \\
Corporate Image & 0,914 & 1,094 & $\begin{array}{c}\text { Existence } \\
\text { It has Multicolonierity } \\
\text { Existence }\end{array}$ \\
\hline
\end{tabular}

Source: SPSS Ver.23 Output Processed (2020)

From the table. 5 shows that the VIF value has symptoms of multicollinearity if VIF $>10$ and the Tolerance value $<0.10$. So, it can be seen that Service Quality (X1) and Corporate Image (X2) both have a VIF value of $1.094>10$ and a Tolerance value of $0.914<0.10$, which means that there was influence between the independent variables.

\section{Heteroscedasticity Test}

The heteroscedasticity test is used to test whether in a regression model there is a variance difference from the existing data residuals (Nanincova, 2019). In this study, the analysis of the scatter plot between the predictive value of the dependent variable (ZPRED) and its residual (SRESID) was carried out. The results were as follows: 


\section{Graph 1: Heteroscedasticity-Dependent Variable} Test Results: Customer Loyalty

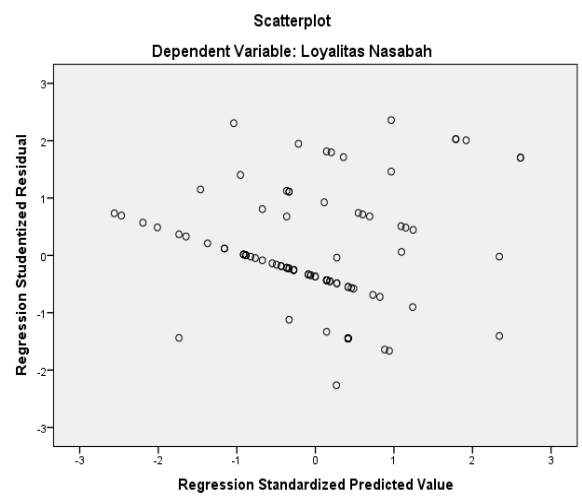

Source: SPSS Ver.23 Output Processed (2020)

Graph. Fig. 1 shows that the points in the graph form a regular pattern, so it can be concluded that in this study heteroscedasticity occurred (disturbances arise due to unequal variants). As a consequence of the heteroscedasticity problem and to strengthen the results above, it was necessary to do the Park test by regressing the independent variables to the residual Ln value squared, and the results of the $\mathrm{t}$ significance value were $0.397>0.05$, so there was no heteroscedasticity $\alpha=5 \%$ ).

\section{Results of Simple Linear Regression Analysis}

Multiple linear regression analysis was conducted to determine the effect of independent variables (Service Quality and Corporate Image) on the dependent variable (Customer Loyalty) BPRS Baktimakmur Indah Sepanjang, Sidoarjo. The results of the analysis were presented in the following table:

Table 6. Summary of Multiple Regression Analysis

\begin{tabular}{lcccc}
\hline \multicolumn{1}{c}{$\begin{array}{c}\text { Independent } \\
\text { Variable }\end{array}$} & $\begin{array}{c}\text { Coefficient } \\
(\boldsymbol{\beta})\end{array}$ & t-value & Sig & VIF \\
\hline Service Quality & 0,028 & 0,851 & 0,397 & 1,094 \\
Corporate Image & 0,260 & 3,653 & 0,000 & 1,094 \\
\hline Constant & & & & 13,509 \\
F-value & & & & 8,696 \\
Adjusted R & & & 0,135 \\
R Square & & & 0,152 \\
Multiple R & & & 0,390 \\
Sample (n) & & & 0,000 \\
Significant $(\alpha)$ & & & \\
\hline
\end{tabular}

Source: Processed Secondary Data (2020) 
Based on the results of the calculations in Table 6 , the linear regression equation was obtained as follows:

$$
(\mathrm{Y})=13,509+0,028 S E R V I C E+0,260 C O I M A G E+e
$$

Following the regression equation, it can be interpreted that the constant value was 13.509 , which means that if the variable service quality and corporate image and $e$ are constant (zero), then customer loyalty was 13.509. The table above showed that the coefficient of determination $\left(\mathrm{R}^{2}\right)$ was 0.152 or $15.2 \%$, meaning that the dependent variable that occurred can be influenced by the independent variable by $15.2 \%$ while the remaining $39 \%$ was influenced by other variables outside the regression model.

The $\mathrm{F}$ test is used to determine the effect of independent variables simultaneously on the dependent variable (Ayuwardani \& Isroah, 2018). The amount of F-value was $8.696>$ F-table 3.07 means that the regression model was correct and feasible. This showed that simultaneously there was a positive and significant influence between service quality and corporate image on customer loyalty. So that $\mathrm{H}_{0}$ was rejected and $\mathrm{H}_{1}$ was accepted.

The t-test is used to determine the effect of the level of significance of the partial relationship between each independent variable (service quality and corporate image) (Zulkarnain et al., 2020). This is as shown in Table 6 the regression test can be explained as follows:

$$
\begin{aligned}
& \text { Table 7. Testing the Regression Hypothesis with T Value: Service Quality } \\
& \begin{array}{cl}
\text { H1 = Service Quality } \rightarrow \text { Customer Loyalty (-) } \\
\hline \mathrm{H}_{\circ}: \beta_{1}=0 & \begin{array}{l}
\text { There is no significant effect of service quality on customer } \\
\text { loyalty of BPRS Baktimakmur Indah Sepanjang Sidoarjo. }
\end{array} \\
\mathrm{H}_{1}: \beta_{1} \neq 0 & \begin{array}{l}
\text { There is a significant effect of service quality on customer } \\
\text { loyalty of BPRS Baktimakmur Indah Sepanjang Sidoarjo. }
\end{array} \\
\hline
\end{array}
\end{aligned}
$$

Source: Data Processed (2020)

Based on Table 6, the service quality had no significant effect on customer loyalty by 0.028 . This showed that the $\mathrm{t}$-value of $0.851<\mathrm{t}$-table of 3.592 which means insignificant, and the p-value of $0.39>0.05$ means that it was also insignificant. Thus $\mathrm{H}_{1}$ was rejected and $\mathrm{H}_{0}$ was accepted, meaning that there was no significant effect of service quality on customer loyalty of BPRS Baktimakmur Indah Sepanjang Sidoarjo.

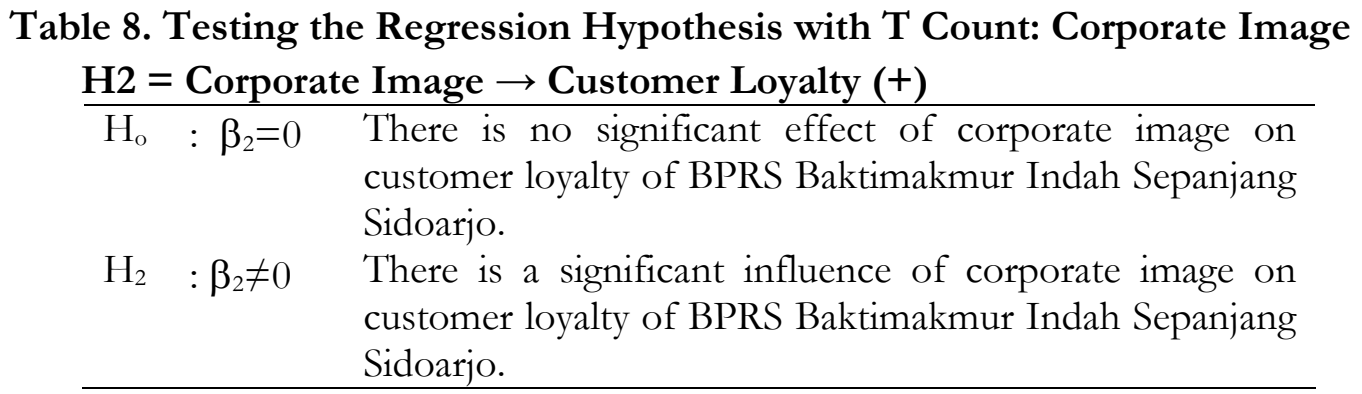

Source: Data Processed (2020)

Based on the exposure of Table 6 , the corporate image had a significant effect on customer loyalty by 0.260 . It was shown that the t-count value was $3.653>$ from the t-table 3.592 . This means that it was significant, and the p-value of $0.000<0.05$ means that it was also significant. Thus, H2 was accepted and Ho was rejected, meaning that there was a significant effect of corporate image on customer loyalty of BPRS Baktimakmur Indah Sepanjang Sidoarjo. 


\section{Hypothesis Test}

\section{Effect of Service Quality on Customer Loyalty}

The results of the analysis showed that service quality has no significant effect on customer loyalty by 0.028 . It was indicated that the $\mathrm{t}$-value value was $0.851<\mathrm{t}$-table 3.592 which means it is not significant, and the p-value was $0.39>0.05$, which means it is also not significant. This shows that if the service quality gets lower with the assumption that other variables are constant, the service quality will decrease. The low service quality can be seen in each indicator which was measured based on the aspects of fulfilled expectations, attention, and responsiveness. The direction of the influence given was negative, which means that the effect is unidirectional and insignificant. This means that the first hypothesis is rejected. Thus, customers who are reluctant to put their hopes on service quality will tend to have low loyalty. Conversely, a company that is committed to quality and consistently provides quality service will enjoy a competitive advantage so that the company can easily build loyalty and build successful customer relationships.

The results of this study are in line with the empirical of Napitupulu \& Lukiyana (2017) which states that service quality does not have a significant effect on loyalty (Oktrima \& Riani, 2019). The direction of the influence given was negative, which means that the effect is unidirectional and insignificant. This means that the first hypothesis is rejected. Thus, customers who are reluctant to put their hopes on service quality will tend to have low loyalty. Conversely, a company that is committed to quality and consistently provides quality service will enjoy a competitive advantage so that the company can easily build loyalty and build successful customer relationships. This means that service quality is one aspect that contributes to the success of an organization.

\section{The Influence of Corporate Image on Customer Loyalty}

The results of the analysis showed that corporate image has a significant effect on customer loyalty by 0.260 . It was shown that the $t$-count value was $3.653>$ the $t$-table 3.592 . This means that it is significant, and the p-value of $0.000<0.05$ means that it is also significant. This shows that if the corporate image is high, customer loyalty will increase (Susanto \& Subagja, 2019). The high corporate image can be seen in each measured indicator based on the characteristics, reputation, and impression aspects, as well as the relationship between BPRS Baktimakmur Indah Sepanjang employees with customers. This research is in line with Mutmainah's empirical point that corporate image has a significant effect on customer loyalty (Mutmainnah, 2017). Customer loyalty will increase if it can give a good impression through its image and if BPRS Baktimakmur Indah Sepanjang remains consistent in maintaining customer trust by being a healthy bank and always carrying out clean banking practices.

\section{The Effect of Service Quality and Corporate Image on Customer Loyalty}

The influence of the independent variable service quality (X1) and corporate image (X2) simultaneously with customer loyalty (Y) BPRS Baktimakmur Indah Sepanjang Sidoarjo shows quite strong criteria. In the problem being studied, it was known that F-value (8.696) > F-table (3.07) then $\mathrm{Ho}$ is rejected and $\mathrm{H}_{1}$ is accepted so that the regression is correct and feasible. This means, together there is a significant effect of service quality and corporate image on customer loyalty of BPRS Baktimakmur Indah Sepanjang Sidoarjo. Even though the R2 value in the calculation was $15.2 \%$. This means that the variable customer loyalty that occurs can be explained by using a variable service quality and corporate image that has an effect of $15.2 \%$. So that the size of customer loyalty is not only influenced by these independent variables, such as research by Rahman (2019), Purnama \& Hidayah (2019), and Pradana et al. (2019) which not only examines the service quality variable but also examines other variables such as innovation and complaint handling. 


\section{Indicators in Service Quality Variables that Have the Most Dominant Influence on Customer Loyalty}

Based on the results of the average or mean calculation of each variable indicator, it can be seen that the indicator that has the most dominant influence of the Service Quality variable on customer loyalty is the indicator of Fulfilled Expectations, especially in terms of Pick-Up Service provided by BPRS Baktimakmur Indah Sepanjang, Sidoarjo with an average value (mean) of 2.66 and consistency of service fulfillment as promised with an average value (mean) of 2.75.

\section{Indicators in the Corporate Image Variable that Have the Most Dominant Influence on Customer Loyalty}

Based on the results of the average or mean calculation of each variable indicator, it can be seen that the indicator that has the most dominant influence of the Corporate Image variable on customer loyalty is the indicator of company characteristics, especially in terms of the strategic location of the BPRS Baktimakmur Indah Sepanjang, Sidoarjo and easy accessibility to customers with an average value (mean) of 2.66 and consistency of service fulfillment as promised, namely free monthly admin fees on all savings with an average value (mean) of 2.75.

\section{CONCLUSION}

Based on the results of the discussion, it can be concluded that Service Quality has a negative or insignificant effect on customer loyalty. This means that not all customers experience service quality based on the aspects of fulfilled expectations, attention, and responsiveness. Meanwhile, Corporate Image has a positive or significant effect on customer loyalty. This means that the better the customer's perception or impression of the company's image, the higher the level of customer loyalty. The simultaneous influence of Service Quality and Corporate Image has a quite strong significance in influencing customer loyalty, even though the coefficient of determination is $15.2 \%$. In the service quality variable, the indicators of fulfilled expectations, especially in providing pick-up service and the suitability of the promised service is the indicator that has the most dominant influence on customer loyalty of BPRS Baktimakmur Indah Sepanjang Sidoarjo. Meanwhile, in the corporate image variable, the indicator for the location of the BPRS Baktimakmur Indah is strategic and easily accessible to customers, which is the characteristic of the company, which is the indicator that has the most dominant influence on customer loyalty of BPRS Baktimakmur Indah Cabang Sepanjang Sidoarjo.

The results of this study imply that it is suggested for company management to realize that customer loyalty has an important role in the sustainability of a business. So that to build loyal customers, BPRS needs to improve service quality and corporate image. Consumers become loyal because they feel satisfied and want to return to transactions continuously. This study only examines the effect of service quality and company image in creating customer loyalty for savings at BPRS Baktimakmur Indah Cabang Sepanjang, Sidoarjo. Therefore, for further research, it is expected to develop other variables that influence customer loyalty as well.

\section{REFERENCES}

Abshari, D. I., \& Hasib, F. F. (2018). Factors Affecting the Deposit Funds of Sharia Banks in Indonesia Year 2010-2015. Jurnal Nisbah, 4(1), 22-33.

Andra Miranthi, I. (2017). Pengaruh Citra Perusahaan, Kualitas Layanan, dan Persepsi Harga Terhadap Minat Beli Ulang Melalui Kepuasan Pelanggan Sebagai Variabel Intervening (Studi pada Penumpang New Atlas Taksi Semarang). Diponegoro Journal of Management, 6(3), 1-8.

Apriyanti, H. W. (2017). Perkembangan Industri Perbankan Syariah di Indonesia: Analisis Peluang dan Tantangan. MAKSIMUM, 1(1), 16-23.

Ashraf, S., Ilyas, R., Imtiaz, M., \& Ahmad, S. (2018). Impact of Service Quality, Corporate Image and Perceived Value on Brand Loyalty with Presence and Absence of Customer Satisfaction: A Study of four Service Sectors of Pakistan. International Journal of Academic Research in Business 
and Social Sciences, 8(2), 452-474. https://doi.org/10.6007/IJARBSS/v8-i2/3885

Asrina, \& Bulutoding, L. (2017). Pengaruh Labelisasi Halal Terhadap Keputusan Konsumen dalam Pembelian Produk Kosmetik di Kota Makassar (Studi Kasus pada Giant Supermarket Alauddin). Pemasaran, 1-16. journal.uin-alauddin.ac.id/index.php/Iqtisaduna/article/.../2307 Ayuwardani, R. P., \& Isroah. (2018). The Influence of Financial and Non-Financial Information to Underpricing Stock Prices When Initial Public Offering (Empirical Study on Go Public Companies on the Indonesia Stock Exchange Period 2011-2015). Jurnal Nominal, VII(1), 143158.

Badan Pusat Statistik. (2020). Bank dan Kantor Bank, 2014-2019. Https://Www.Bps.Go.Id/. https://www.bps.go.id/statictable/2020/01/21/2082/bank-dan-kantor-bank-20142019.html

Dewi, P. S. A., \& Suprapti, N. W. S. (2018). Membangun Loyalitas Pelanggan Melalui Kepuasan yang Dipengaruhi oleh Kualitas Produk, Persepsi Harga dan Citra Merek (Studi pada Produk Smartphone Merek Oppo). Matrik: Jurnal Manajemen, Strategi Bisnis Dan Kewirausahaan, 12(2), 87-98. https://doi.org/10.24843/MATRIK:JMBK.2018.v12.i02.p01

Habibi, M. L., \& Yudha, A. T. R. C. (2017). Membangun Integrated Takaful Dan Wakaf Model Dalam Upaya Meningkatkan Kemanfaatan Pemegang Polis. Al-Uqud: Journal of Islamic Economics, 1(2), 139. https://doi.org/10.26740/jie.v1n2.p139-155

Haeriah, \& Rahayu, Y. I. (2018). Pengaruh Kualitas Layanan, Kepercayaan, dan Image Terhadap Kepuasan Debitur Bank Sultra. Jurnal Ilmu Manajemen, 4(2012), 54-67.

Hanif, R., \& Fitri, R. (2018). Pengaruh Pembiayaan dan Efisiensi Operasi Terhadap Pencapaian Laba Pada BPR Syariah di Jawa Timur. JIBEKA: Jurnal Ilmiah Bisnis Dan Ekonomi Asia, 12(2), $1-6$.

Hidayat, Y. R. (2018). Analisis Peluang Dan Tantangan Lembaga Keuangan Syariah Untuk Meningkatkan Daya Saing Menghadapi Masyarakat Ekonomi Asean. Amwaluna: Jurnal Ekonomi Dan Kenangan Syariah, 2(2), 13-32. https://doi.org/10.29313/amwaluna.v2i2.3755

Ilham, M., \& Hariyani, I. (2020). Memahami Peran Lembaga Pembiayaan Syari'ah dalam Meningkatkan Aksesibilitas Keuangan UMKM pada Masa Pandemi Covid19. Widya Yuridika: Jurnal Hukum, 3(2), 257-270.

Kusumastuti, A. L., \& Kodir, M. A. (2019). Analisis Kualitas Pelayanan Terhadap Loyalitas Nasabah Pada Bank Jateng Cabang Pembantu Sampangan. Keunis Majalah Ilmiah, 7(1), 49-63. https://doi.org/10.32497/keunis.v7i1.1532

Mandong, I. S., Tumbel, A. L., \& Tawas, H. N. (2017). Factors Affecting Customer Loyalty on PT. Bank BNI (Persero) Tbk Manado Branch Office. Jurnal EMBA, 5(3), 3210-3219.

Manurung, R., \& Fitrawaty. (2016). Analisis Tingkat Persaingan Industri Perbankan di Indonesia. QE Journal, 5(3), 149-163. https://qe-journal.github.io/publications/QEJ-Vol-05-No-03Article-03-Romauli-Manurung-\&-Fitrawaty.pdf

Mutmainnah. (2017). Pengaruh Kualitas Layanan dan Citra Perusahaan Terhadap Kepuasan dan Loyalitas Nasabah. Jurnal Manajemen Dan Pemasaran Jasa, 10(2), 201-216. https:// doi.org/10.25105/jmpj.v10i1.2344

Nanincova, N. (2019). Pengaruh Kualitas Layanan Terhadap Kepuasan Pelanggan Noach Cafe and Bistro. $A G O R A, 7(2), 1-5$.

Nasfi, Rahmad, \& Sabri. (2020). Pengaruh Kualitas Pelayanan Terhadap Kepuasan Nasabah Perbankan Syariah. Ekonomika Syariab: Journal of Economic Studies, 4(1), 19-39.

Naufal, F. M., \& Firdaus, A. (2017). Analisis Efisiensi Bank Pembiayaan Rakyat Syariah (BPRS) Wilayah Jabodetabek dengan Pendekatan Two Stage Data Envelopment Analysis (DEA). EQUILIBRIUM: Jurnal Ekonomi Syariah, 5(2), 196-220.

Nurhayati, E. (2018). Strategi Peningkatan Produktivitas Untuk Mencapai Target Produktivitas dan Efisiensi Perusahaan. IEJST (Industrial Engineering Journal of The University of Sarjanawiyata Tamansiswa), 2(1), 62-68.

Oktrima, B., \& Riani, N. (2019). Pengaruh Perputaran Kas dan Perputaran Piutang Terhadap Return on Investment (ROI) pada PT. Semen Indonesia (Persero) Tbk Periode Tahun 2008 - 2017. Jurnal Ekonomi Efektif, 2(1), 101-109. 
Padilah, T. N., \& Adam, R. I. (2016). Analisis Regresi Linier Berganda dalam Estimasi Produktivitas Tanaman Padi di Kabupaten Karawang. FIBONACCI: Jurnal Pendidikan Matematika Dan Matematika, 5(2), 117-128.

Pradana, M. B. V., Wahab, Z., Widad, A., \& Gunarto, M. (2019). Studi Kepuasan dan Loyalitas Nasabah melalui Kualitas Layanan dan Citra Bank Sumsel Babel. INOBIS: Jurnal Inovasi Bisnis Dan Manajemen Indonesia, 02(2), 206-219.

Pratomo, G. (2017). Strategi dan Interaksi Industri Perbankan Konvensional dan Syariah Pasca ASEAN Economic Community (AEC) di Indonesia: Sintesa Analytic Hierarchy Process dan Game Theory. E-Jurnal: Spirit Pro Patria, III(2), 190-202.

Purbasari, D. M., \& Purnamasari, D. L. (2018). Pengaruh Kualitas Pelayanan dan Kepuasan Pelanggan Terhadap Pembelian Ulang. Jurnal Inspirasi Bisnis Dan Manajemen, 2(202), 43-54.

Purnama, R., \& Hidayah, A. A. (2019). Pengaruh Kualitas Pelayanan, Citra Perusahaan, dan Kepercayaan Terhadap Kepuasan Pelanggan Serta Pengaruhnya Terhadap Loyalitas Pelanggan. Tirtayasa EKONOMIKA, 14(2), 187-203.

Putra, M. C. S. D., \& Ekawati, N. W. (2017). Pengaruh Inovasi Produk, Harga, Citra Merek dan Kualitas Pelayanan Terhadap Loyalitas Pelanggan Sepeda Motor Vespa. E-Jurnal Manajemen Unud, 6(3), 1674-1700.

Rahman, S. (2019). The Effect of Quality Service and Innovation Toward Customer Satisfaction on PLN (Persero) Area Manado. Jurnal EMBA, 7(1), 301-311.

Samsul, \& Ismawati. (2020). Tingkat Pemahaman Mahasiswa Terhadap Produk-Produk Perbankan Syariah. Al-Mashrafiyah: Jurnal Ekonomi, Keuangan Dan Perbankan Syariah, 4(1), 67-78.

Sholeha, L., Djaja, S., \& Widodo, J. (2018). Pengaruh Kualitas Pelayanan Terhadap Kepuasan Pelanggan di Ahass Sumber Jaya Maha Sakti Kecamatan Rogojampi Kabupaten Banyuwangi. Jurnal Pendidikan Ekonomi: Jurnal Ilmiah Ilmu Pendidikan, Ilmu Ekonomi, Dan Ilmu Sosial, 12(1), 15-25. https://doi.org/10.19184/jpe.v12i1.6465

Silalahi, U. (2012). Metode Penelitian Sosial. Refika Aditama.

Sugiyono. (2011). Metode Penelitian Kuantitatif, Kualitatif dan RnD. Alfabeta.

Sugiyono. (2012). Metode Penelitian Kuantitatif, Kualitatif, dan Kombinasi; Mixed Methods. Alfabeta.

Sukoco, A., Anshori, Y., \& Yudha, A. T. R. C. (2020). Strategies To Increase Market Share For Histopatological Equipment Products (Brand Sakura): Case Study in Management of a Sole Agent Company. SINERGI, Volume 10 Number 2 September 2020 SINERGI, Volume 10 Number 2 September 2020, 10(2), 19-26.

Sulaeman, M., Sudiarti, S., Mulyati, S., Sundarsih, D., \& Kustantini, D. (2017). Pengaruh Kualitas Layanan dan Kewiraniagaan Terhadap Kepuasan Nasabah Kredit Pensiun serta Dampaknya pada Loyalitas Nasabah. Jurnal Aplikasi Bisnis, 17(2), 40-61.

Susanto, P. H., \& Subagja, I. K. (2019). Pengaruh Kualitas Layanan, Kepuasan Nasabah dan Citra Perusahaan Terhadap Loyalitas Nasabah PT. Bank Central Asia Tbk Kantor Cabang Pondok Gede Plaza. Jurnal Manajemen Bisnis Krisnadwipayana Puteri, 7(1), 69-84. https://doi.org/10.35137/jmbk.v7i1.249

Syarifudin, Nurlailah, \& Yudha, A. T. R. C. (2020). The Allocation of 'Tabarru' Fund Underwriting Surplus of IPLAN Sharia Product in PT. Asuransi Jiwa Generali Indonesia. Jumal Ekonomi Syariah Teori Dan Terapan, 7(9), 1804. https://doi.org/10.20473/vol7iss20209pp1804-1817

Thungasal, C. E., \& Siagian, H. (2019). Pengaruh Kualitas Layanan dan Harga Terhadap Loyalitas Pelanggan Melalui Kepuasan Pelanggan pada Hotel Kasuari. AGORA, 7(1), 1-7.

Tjiptono, F., \& Chandra, A. G. (2011). Service Quality \& Satisfaction. ANDI.

Tuju, R. E., \& Loindong, S. (2018). Effect of Service Quality and Yamaha Motorcycle Products on Customer Satisfaction of PT. Hasjrat Abadi in Manado. Jurnal EMBA, 6(3), 1798-1807.

Wati, F. A., \& Isroah. (2019). The Effect of Neighborhood Peer, Family Environment and Learning Motivation Toward Achievement of Accounting in Class XII Social SMA Negeri 1 Sewon Academic Year 2018/2019. Jurnal Pendidikan Akuntansi Indonesia, XVII(1), 112-126.

Wijanarko, A., \& Rachmawati, L. (2020). Pengaruh Literasi Keuangan Syariah, Islamic Branding, dan Religiusitas Terhadap Keputusan Mahasiswa dalam Memilih Layanan Keuangan Syariah. Jurnal Ekonomika Dan Bisnis Islam, 3(1), 104-116. 
Yudha, A. T. R. C., Pauzi, N. S., \& Azli, R. binti M. (2020). The Synergy Model for Strengthening the Productivity of Indonesian Halal Industry. Al-Uqud: Journal of Islamic Economics, 4(2), 186199. https://doi.org/10.26740/al-uqud.v4n2.p186-199

Zulkarnain, R., Taufik, H., \& Ramdansyah, A. D. (2020). Pengaruh Kualitas Pelayanan dan Kualitas Produk Terhadap Loyalitas Nasabah dengan Kepuasan Nasabah Sebagai Variabel Intervening (Studi Kasus pada PT. Bank Syariah Mu’amalah Cilegon). Jurnal Manajemen Dan Bisnis, 1(2), 87-110.

Zumaroh. (2018). Prospek Pengelolaan Keuangan Bank Syariah di Indonesia. FINANSLA: Jurnal Akuntansi Dan Perbankan Syariah, 01(02), 199-224. http://ejournal.metrouniv.ac.id/index.php/FINANSIA/article/download/1337/1164 